\title{
SLAUGHTER QUALITIES OF YOUNG PIGS OF LANDRAS AND WELSH
}

Kozir V. S., Institute of Grain Crops of NAAS

Tsereniuk O. M., Akimov O. V., Institute of Animal Science NAAS Ukraine,

Babicz M., University of Life Sciences in Lublin, Poland

The aim of the research, the results of which are presented in the article, was a comparative study of the slaughter qualities of the leading lines of boars of the Welsh and Landrace breeds of domestic selection. The research was carried out based on the slaughterhouse of FG "Shubske" of Bohodukhiv district of Kharkiv region, based on a breeding breeder for keeping Welsh pigs during 2020. The research was conducted based on traditional approaches. Slaughter was performed at a live weight of $100 \mathrm{~kg} \pm$ $5 \%$. The slaughter traits were evaluated according to the following traits: the thickness of the lard at different points, the slaughter yield, the length of the half-carcass, the length and width of the bacon half and the area of the muscle cell. According to the results of the assessment of slaughter qualities of young animals, no significant difference between the groups was found. Thus, the average pre-slaughter weight ranged from 98.45-99.40 kg, slaughter weight - 73.80-75.00 kg and, accordingly, slaughter yield 75.03-75.44\%. Such insignificant differences in slaughter yield between different lines of pigs are explained by the fact that both breeds are similar in appearance and level of productivity, are in the same conditions of keeping and feeding (in one farm) and are selected by the same generation principle. Regarding the linear measurements of halfcarcasses, the differences between the groups were insignificant, but in terms of the measurements of the bacon half of the Welsh pigs, there were probably different traits in comparison with the Landrace pigs. However, despite the lack of probable differences between the breeds of Landrace and Welsh, the length of the bacon half and the area of the muscular membrane - Landrace were slightly higher than in Welsh. Analysis of fat measurements showed that the differences between the groups were insignificant. At the same time, despite the absence of probable differences between the average breeds (groups IV and VII), animals of groups II and III were marked by slightly leaner carcasses compared to Landrace pigs ( $p<0.05$ ). The differences between Landrace and Welsh breeds are insignificant in terms of the slaughter qualities of young animals. Probable differences are found only between young animals from individual lines in the Landrace breed and their peers in the Welsh breed. The general level of meat in both breeds is at a high enough level, which indicates the possibility of further use in breeding work with these breeds of all boars evaluated in these studies.

Keywords: pig breeding, young pigs, slaughter traits, meat, lines.

УДК [639.3.043:577.112.34]:597.552.512

DOI 10.32900/2312-8402-2020-124-104-114

\section{ВПЛИВ АМІНОКИСЛОТНОГО ЖИВЛЕННЯ НА ПРОДУКТИВНІСТЬ ЦЬОГОЛІТКІВ РАЙДУЖНОЇ ФОРЕЛІ}

Кондратюк В.М., к. с.-Г. Н., доцент, Національний університет біоресурсів і природокористування України

У статті розглянуто питання ефективності використання повнораціонних комбікормів з різними рівнями лізину і метіоніну за вирощування иььоголітків райдужної форелі до маси 10 г. Метою досліду передбачалося встановити вплив різних рівнів амінокислотного живлення форелі на показники ї̈ продуктивності. 
Для иьього за методом аналогів було сформовано п'ять піддослідних груп иььоголітків. Дослід тривав 45 діб і поділявся на два періоди: зрівняльний (5 діб) та основний (40 діб). У зрівняльний період піддослідна риба споживала комбікорм контрольної групи. В основний період рівень лізину і метіоніну в експериментальних комбікормах для різних піддослідних груп форелі коливався від 2,8 до 3,2 \% та від 0,90 до 1,10\% відповідно.

У результаті проведених досліджень встановлено, щуо використання у годівлі изьоголітків форелі масою до 10 г комбікормів з підвищеною амінокислотною поживністю $(3,1 \%$ лізину, 1,05 \% метіоніну) супроводжується збільшенням їхньої маси на 9,2\% $(p<0,05)$ та інтенсивності росту - на 4,1-9,3\%, порівняно 3 аналогами, що споживали корм із вмістом лізину 3,0 \% та метіоніну 1,0\%. 3меншення цих амінокислот до рівнів 2,8 і 0,9\% відповідно сприяє вірогідному зменшенню $(p<0,01)$ маси риб на 14,1\%, та зниженню інтенсивності росту на 8,7$17,3 \%$.

Доведено, щзо різний рівень амінокислотного живлення молоді форелі достовірно $(p<0,01)$ впливав на масу піддослідних риб. Частка впливу даного фактору становить 61,4\%, щзо на 22,8\% більше, порівняно з впливом інших факторів.

У процесі досліджень було визначено, що за вирощування иьоголітків райдужної форелі до маси 10 г згодовування їм комбікормів із вмістом лізину і метіоніну на рівні 3,1 i 1,05\% сприяє зниженню витрат корму на одиницю приросту маси на 12,5\%, порівняно з використанням кормів з рівнями ицих амінокислот 2,8 $i$ 0,9\% відповідно. При иььому збереженість піддослідних риб упродовж усього досліду відповідала нормативним показникам у форелівниитві і перебувала у межах 76,0-77,3\%.

Аналізом отриманих рибницьких результатів встановлено, щุо за виробниитвва продукції форелівництва за показниками максимальної продуктивності та економічними критеріями оптимізащії рекомендується для годівлі иььоголітків райдужної форелі використовувати повнорачіонні комбікорми з рівнем лізину 3,1\% та метіоніну $1,05 \%$.

Ключові слова: райдужна форель, годівля риб, комбікорми, лізин, метіонін, продуктивність, економічна ефективність.

Збалансована годівля риб на усіх етапах її вирощування є одним з найважливіших факторів, який впливає на виробництво продукції та економічні показники ведення галузі [1]. Не останню роль в цьому відіграє амінокислотний склад кормів. Білкова недостатність у риб розвивається як за прийому одноманітного білкового харчування, так і за нестачі окремих амінокислот в їхньому раціоні. Специфічні прояви недостатності в ньому амінокислот в цілому схожі з ознаками неповноцінного харчування і не мають яскраво вираженої клінічної картини. До них відносять зниження швидкості росту, резистентності організму, втрату апетиту тощо [2-4].

Повністю збалансований комбікорм має вирішальне значення, як для збільшення масонакопичення, так і для зведення до мінімуму забруднення води азотними метаболітами. Особливо важливе значення при цьому мають лімітуючі амінокислоти лізин і метіонін $[5,6]$.

Лізин необхідний для регулювання обміну азоту і вуглеводів, синтезу найважливіших білків - нуклеотидів і хромопротеїдів. Досить важливу роль лізин виконує в оптимізації росту і розвитку організму риб, у формуванні кісткових тканин і нормалізації функцій різних органів. Нестача лізину спричинюяє втрату апетиту, порушення кальцієвого обміну, гальмування росту, загальне виснаження. 
Проте, небажане і передозування лізину, що викликає раціонний дисбаланс амінокислот, внаслідок чого гальмується інтенсивність росту, погіршується фізіологічний стан, порушується обмін речовин [6-8].

Вміст метіоніну у раціонах риб досить часто наближається до межі дефіциту. В разі його нестачі гальмується інтенсивність росту, порушуються функції печінки, виникає атрофія м'язів. Дефіцит метіоніну особливо швидко призводить до жирової інфільтрації печінки, яка дещо збільшується і набуває глинистого відтінку. Метіонін виконує роль донора метильних груп, які беруть участь в утворенні багатьох сполук [9-11].

Таким чином, вивчення питання впливу різного амінокислотного живлення цьоголітків райдужної форелі в сучасних промислових умовах холодноводних рибницьких господарств України є необхідним та актуальним.

Матеріал та методи досліджень. Експериментальні дослідження на цьоголітках райдужної форелі Oncorhynchus mykiss (Walbaum, 1792) проведені в умовах господарства «Шипот» Перечинського району Закарпатської області.

Метою науково-господарського досліду передбачалося встановити вплив різних рівнів амінокислотного живлення цьоголітків форелі на показники їхньої продуктивності.

Для цього за методом аналогів сформовано п’ять піддослідних груп риб (табл. 1).

Таблиия 1

Схема науково-господарського досліду

\begin{tabular}{|c|c|c|c|c|c|c|}
\hline \multirow{4}{*}{ Група риб } & \multirow{4}{*}{$\begin{array}{c}\text { Щільність } \\
\text { посадки на } \\
\text { початок } \\
\text { досліду, } \\
\text { екз./м² }\end{array}$} & \multirow{4}{*}{$\begin{array}{c}\text { Середня } \\
\text { маса на } \\
\text { початок } \\
\text { досліду, г }\end{array}$} & \multicolumn{4}{|c|}{ Періоди досліду } \\
\hline & & & \multicolumn{2}{|c|}{$\begin{array}{l}\text { зрівняльний } \\
\text { (5 діб) }\end{array}$} & \multicolumn{2}{|c|}{$\begin{array}{c}\text { основний } \\
(40 \text { діб) }\end{array}$} \\
\hline & & & \multicolumn{4}{|c|}{ вміст в 1 кг комбікорму, \% } \\
\hline & & & лізину & метіоніну & лізину & метіоніну \\
\hline 1- контрольна & 200 & $1,03 \pm 0,092$ & \multirow{5}{*}{3,0} & \multirow{5}{*}{1,00} & 3,0 & 1,00 \\
\hline 2- дослідна & 200 & $1,06 \pm 0,078$ & & & 2,8 & 0,90 \\
\hline 3- дослідна & 200 & $1,01 \pm 0,068$ & & & 2,9 & 0,95 \\
\hline 4- дослідна & 200 & $1,05 \pm 0,089$ & & & 3,1 & 1,05 \\
\hline 5- дослідна & 200 & $1,02 \pm 0,102$ & & & 3,2 & 1,10 \\
\hline
\end{tabular}

У зрівняльний період піддослідна риба споживала комбікорм контрольної групи, де рівні лізину і метіоніну, а також їхнє співвідношення відповідали встановленим нормам [3, 12]. В основний період молодь усіх груп отримували подібний раціон, за винятком рівня лізину і метіоніну у ньому. Згадані амінокислоти додавали у тій чи іншій пропорції, що було передбачено схемою досліду. Поживність експериментальних комбікормів наведено у таблиці 2.

Годівлю цьоголітків райдужної форелі проводили 6 раз на добу, в денний час через рівні проміжки. Необхідну кількість корму розраховували відповідно до показників індивідуальної маси молоді та температури середовища на момент годівлі.

Щільність посадки піддослідних риб на початку досліду становила 200 екз./м². Вирощування молоді проводили в ставах за рівня води в них 1 м. Умови утримання цьоголітків протягом періоду досліду відповідали загальновизнаним у форелівництві $[13,14]$.

Контрольні лови піддослідної форелі проводили раз на 5 діб. Зважуванню на електронних вагах піддавали по 100 екз. молоді з кожної групи. Результати до- 
сліджень опрацьовані методом варіаційної статистики [15] за допомогою програмного забезпечення MS Excel i STATISTICA 7.0. з використанням вбудованих статистичних функцій.

Таблиия 2

Вміст у 1 кг комбікорму, \%

\begin{tabular}{|l|c|c|c|c|c|}
\hline \multirow{2}{*}{\multicolumn{1}{|c|}{ Показник }} & \multicolumn{5}{c|}{ Групи риб } \\
\cline { 2 - 6 } & $\mathbf{1 - a}$ & $\mathbf{2 - a}$ & $\mathbf{3 - я}$ & $\mathbf{4 - a}$ & $\mathbf{5 - a}$ \\
\hline Обмінна енергія, МДж & 17,00 & 17,00 & 17,00 & 17,00 & 17,00 \\
\hline Сирий протеїн & 52,00 & 52,00 & 52,00 & 52,00 & 52,00 \\
\hline Сирий жир & 14,00 & 14,00 & 14,00 & 14,00 & 14,00 \\
\hline Сира клітковина & 1,72 & 1,72 & 1,72 & 1,72 & 1,72 \\
\hline Кальцій & 2,25 & 2,25 & 2,25 & 2,25 & 2,25 \\
\hline Фосфор загальний & 1,50 & 1,50 & 1,50 & 1,50 & 1,50 \\
\hline Лізин & 3,00 & 2,8 & 2,9 & 3,1 & 3,2 \\
\hline Метіонін & 1,00 & 0,9 & 0,95 & 1,05 & 1,10 \\
\hline Вітамін А, тис. МО & 15 & 15 & 15 & 15 & 15 \\
\hline Вітамін $\mathrm{D}_{3}$, тис. МО & 3,5 & 3,5 & 3,5 & 3,5 & 3,5 \\
\hline Вітамін Е, мг & 250 & 250 & 250 & 250 & 250 \\
\hline
\end{tabular}

Результати досліджень. Встановлено, що у основний період досліду, за рахунок різного амінокислотного живлення цьоголітків форелі, спостерігалися помітні зміни у показниках наростання їхньої маси (табл. 3).

На час закінчення досліду (45 доба) вищої маси досягли цьоголітки 4-та 5-ї груп, які переважали аналогів контрольної відповідно на 0,88 та 0,26 г, або на 9,2 та 2,2 \%. У цей же час цьоголітки 2- і 3-ї дослідних груп поступалися за згаданим показником контрольним ровесникам відповідно на 1,65 і 0,67 г, або на 14,1 $(\mathrm{p}<0,01)$ i $5,7 \%$.

Отже, годівля цьоголітків форелі комбікормами зі збільшенням вмістом в них лізину і метіоніну до рівнів 3,1 і 1,05 \% відповідно сприяє збільшенню маси риб, тоді як зменшення вмісту у комбікормах цих амінокислот до рівня 2,8 і 0,9 \% відповідно призводило до достовірного зменшення наростання їхньої іхтіомаси.

Таблиия 3

Маса піддослідних цьоголітків форелі за різного амінокислотного живлення, г

\begin{tabular}{|c|c|c|c|c|c|}
\hline \multirow{2}{*}{$\begin{array}{c}\text { Доба } \\
\text { досліду }\end{array}$} & \multicolumn{5}{|c|}{ Групи риб } \\
\hline & 1-a & 2-a & 3-я & 4-a & $5-a$ \\
\hline 1 & $1,03 \pm 0,092$ & $1,06 \pm 0,078$ & $1,01 \pm 0,068$ & $1,05 \pm 0,089$ & $1,02 \pm 0,102$ \\
\hline 5 & $2,05 \pm 0,137$ & $2,07 \pm 0,129$ & $2,05 \pm 0,171$ & $2,03 \pm 0,153$ & $2,03 \pm 0,146$ \\
\hline 10 & $3,17 \pm 0,191$ & $3,11 \pm 0,160$ & $3,11 \pm 0,138$ & $3,17 \pm 0,215$ & $3,14 \pm 0,201$ \\
\hline 15 & $4,31 \pm 0,212$ & $4,07 \pm 0,194$ & $4,18 \pm 0,175$ & $4,39 \pm 0,207$ & $4,28 \pm 0,269$ \\
\hline 20 & $5,67 \pm 0,261$ & $5,02 \pm 0,225$ & $5,37 \pm 0,236$ & $5,76 \pm 0,260$ & $5,58 \pm 0,302$ \\
\hline 25 & $6,98 \pm 0,293$ & $5,96 \pm 0,259 * *$ & $6,59 \pm 0,303$ & $7,15 \pm 0,285$ & $6,87 \pm 0,320$ \\
\hline 30 & $8,25 \pm 0,314$ & $7,06 \pm 0,281 * *$ & $7,84 \pm 0,295$ & $8,64 \pm 0,328$ & $8,23 \pm 0,341$ \\
\hline 35 & $9,37 \pm 0,365$ & $8,12 \pm 0,347 *$ & $8,89 \pm 0,340$ & $10,00 \pm 0,394$ & $9,51 \pm 0,373$ \\
\hline 40 & $10,55 \pm 0,413$ & $9,10 \pm 0,372 * *$ & $9,95 \pm 0,363$ & $11,33 \pm 0,436$ & $10,75 \pm 0,417$ \\
\hline 45 & $11,71 \pm 0,464$ & $10,06 \pm 0,418^{* *}$ & $11,04 \pm 0,402$ & $12,59 \pm 0,473$ & $11,97 \pm 0,451$ \\
\hline
\end{tabular}


Опис росту цьоголітків форелі за допомогою математичних методів підтвердив висхідну форму кривої росту (рис. 1).

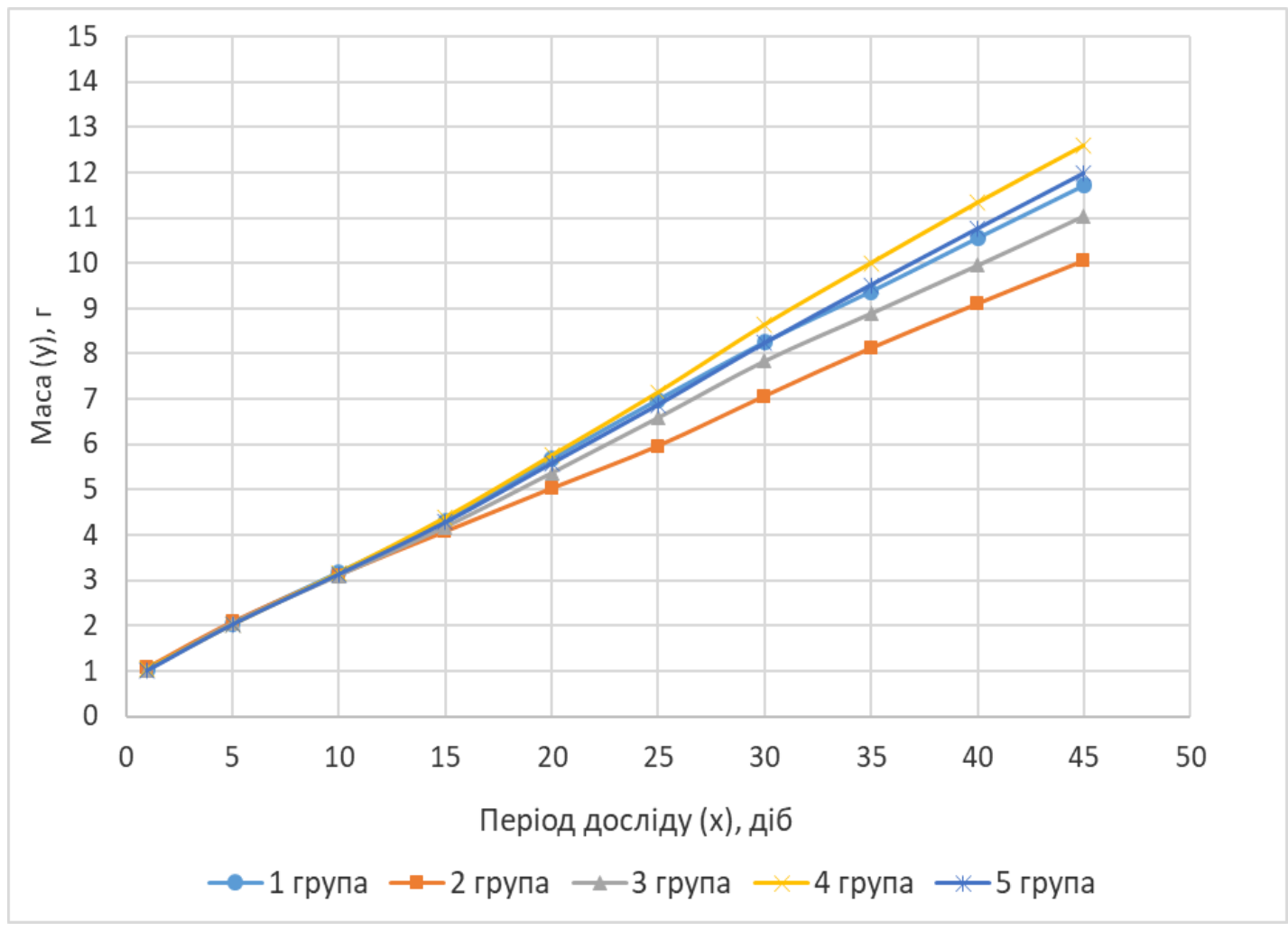

Рис. 1. Графічна модель росту цьоголітків форелі за різного амінокислотного живлення

У досліді цей показник був описаний за допомогою математичної моделі 3 нелінійною характеристикою. За зміною періоду досліду $(x)$, залежно від рівня лізину (Л) і метіоніну (М) у комбікормі, можна спрогнозувати масу цьоголітків $(y)$ :

$$
\begin{aligned}
& 1 \text { група }(3,0 \% \text { Л, } 1,0 \% \mathrm{M}): \\
& \mathrm{y}=-0,0001 \mathrm{x}^{2}+0,2497 \mathrm{x}+0,7423\left(\mathrm{R}^{2}=0,9996\right) ; \\
& 2 \text { група }(2,8 \% \text { Л, } 0,9 \% \mathrm{M}): \\
& \mathrm{y}=-0,0001 \mathrm{x}^{2}+0,207 \mathrm{x}+0,9582\left(\mathrm{R}^{2}=0,9995\right) ; \\
& 3 \text { група }(2,9 \% \text { Л, } 0,95 \% \mathrm{M}): \\
& \mathrm{y}=-0,0002 \mathrm{x}^{2}+0,2357 \mathrm{x}+0,7851\left(\mathrm{R}^{2}=0,9996\right) ; \\
& 4 \text { група }(3,1 \% \text { Л, } 1,05 \% \mathrm{M}): \\
& \mathrm{y}=0,0005 \mathrm{x}^{2}+0,2447 \mathrm{x}+0,7431\left(\mathrm{R}^{2}=0,9995\right) ; \\
& 5 \text { група }(3,2 \% \text { Л, } 1,10 \% \mathrm{M}): \\
& \mathrm{y}=0,0003 \mathrm{x}^{2}+0,2363 \mathrm{x}+0,7717\left(\mathrm{R}^{2}=0,9997\right)
\end{aligned}
$$

Дані дисперсійного аналізу свідчить про те, що різний рівень амінокислотного живлення цьоголітків форелі достовірно $(\mathrm{p}<0,01)$ впливав на масу піддослідних риб. Частка впливу даного фактору становить 61,4 \%, що на 22,8 \% більше, порівняно з впливом інших факторів.

Результати проведених досліджень свідчать про те, що впродовж періоду вирощування цьоголітків характер змін у середньодобових приростах їхньої маси 
залежав від рівня лізину і метіоніну у комбікормі та зміни динаміки масонакопичення (табл. 4).

Таблиия 4

Середньодобові прирости маси цьоголітків форелі за різного амінокислотного живлення, г

\begin{tabular}{|c|c|c|c|c|c|}
\hline \multirow{2}{*}{ Періоди досліду, діб } & \multicolumn{5}{|c|}{ Групи риб } \\
\cline { 2 - 6 } & $\mathbf{1 - a}$ & $\mathbf{2 - a}$ & $\mathbf{3 - я}$ & $\mathbf{4 - a}$ & $\mathbf{5 - a}$ \\
\hline $1-5$ & 0,204 & 0,202 & 0,208 & 0,196 & 0,202 \\
\hline $6-10$ & 0,224 & 0,208 & 0,212 & 0,228 & 0,222 \\
\hline $11-15$ & 0,228 & 0,192 & 0,214 & 0,244 & 0,228 \\
\hline $16-20$ & 0,272 & 0,190 & 0,238 & 0,274 & 0,260 \\
\hline $21-25$ & 0,262 & 0,188 & 0,244 & 0,278 & 0,258 \\
\hline $26-30$ & 0,254 & 0,220 & 0,250 & 0,298 & 0,272 \\
\hline $31-35$ & 0,224 & 0,212 & 0,210 & 0,272 & 0,256 \\
\hline $36-40$ & 0,236 & 0,196 & 0,212 & 0,266 & 0,248 \\
\hline $41-45$ & 0,232 & 0,192 & 0,218 & 0,252 & 0,244 \\
\hline У середньому за основний період & \multirow{2}{*}{0,242} & 0,200 & 0,225 & 0,264 & 0,249 \\
\hline досліду (6-45 діб) & & & & \multicolumn{2}{|c}{} \\
\hline
\end{tabular}

Слід відмітити, що загалом за основний період досліду найвищими середньодобовими приростами маси характеризувалась форель 4-ї групи, що отримувала комбікорм з вмістом лізину і метіоніну на рівні 3,1 і 1,05 \% відповідно, яка за цим показником переважали контрольних на 9,1\%. Цьоголітки форелі 2- і 3-ї дослідних груп, які споживали комбікорм із зниженим вмістом зазначених амінокислот, поступалися аналогам 1-ї групи за згаданим показником у основний період досліду відповідно на 42 і 17 мг. Різниця між ровесниками 2- і 4-ї груп за середньодобовими приростами маси за основний період досліду становила 64 мг.

На основі отриманих даних можна зробити висновок про те, що годівля цьоголітків форелі зі збільшеним вмістом в них лізину і метіоніну до рівнів 3,1 i 1,05 \% відповідно, сприяє підвищенню їхньої маси та середньодобових приростів. Це пов'язано з активізацією обмінних процесів в організмі цьоголітків, що, в свою чергу, покращує показники їхньої продуктивності, тоді як зменшення вмісту цих амінокислот до рівня 2,8 і 0,9 \% відповідно, призводить до протилежного ефекту i відповідно - до зменшення продуктивності риб.

Аналіз витрат кормів свідчить, що використання для годівлі цьоголітків форелі комбікормів із вмістом лізину і метіоніну на рівні 3,1 і 1,05 \% (4-а група) сприяло зниженню витрат комбікормів на 1 кг приросту маси за основний період досліду, порівняно з рибами інших груп. Так, витрати корму на 1 кг приросту маси у цьоголітків 4-ї групи становили 0,787 кг, що на 0,38; 0,98; 0,58 і 0,17 кг менше, ніж у таких 1-, 2-, 3- і 5-ї груп відповідно.

Отже, за вирощування цьоголітків райдужної форелі до маси 10 г згодовування їм комбікормів із вмістом лізину і метіоніну на рівні 3,1 і 1,05\% сприяє зниженню витрат корму на одиницю приросту маси. Що стосується збереженості піддослідних риб, то вона за показниками була близькою і коливалася від 76,0 до $77,3 \%$.

Аналізуючи показники ефективності вирощування цьоголітків форелі можна стверджувати, що за різного амінокислотного живлення вони відрізнялися між собою (табл. 5). 
Таблиия 5

Економічна ефективність вирощування цьоголітків форелі за різного амінокислотного живлення

\begin{tabular}{|l|c|c|c|c|c|}
\hline \multicolumn{1}{|c|}{ Показник } & \multicolumn{5}{|c|}{ Групи риб } \\
\cline { 2 - 6 } & $\mathbf{1 - a}$ & $\mathbf{2 - a}$ & $\mathbf{3 - я}$ & $\mathbf{4 - a}$ & $\mathbf{5 - a}$ \\
\hline $\begin{array}{l}\text { Iхтіомаса на початок основного } \\
\text { періоду досліду, кг }\end{array}$ & 40,02 & 40,7 & 40,18 & 39,95 & 39,95 \\
\hline Збереженість, \% & 76,5 & 76 & 76,6 & 77,3 & 77,1 \\
\hline Іхтіомаса в кінці досліду, кг & 179,16 & 152,91 & 169,13 & 194,64 & 184,58 \\
\hline $\begin{array}{l}\text { Приріст іхтіомаси за основний } \\
\text { період досліду, кг }\end{array}$ & 139,14 & 112,21 & 128,95 & 154,69 & 144,63 \\
\hline $\begin{array}{l}\text { Витрати корму на 1 кг приросту } \\
\text { іхтіомаси, кг }\end{array}$ & 0,825 & 0,885 & 0,845 & 0,787 & 0,804 \\
\hline $\begin{array}{l}\text { Витрати корму на загальний } \\
\text { приріст іхтіомаси, кг }\end{array}$ & 114,79 & 99,31 & 108,96 & 121,74 & 116,28 \\
\hline $\begin{array}{l}\text { Вартість виробництва 1 кг ком- } \\
\text { бікорму, грн }\end{array}$ & 83,37 & 83,19 & 83,28 & 83,46 & 83,55 \\
\hline $\begin{array}{l}\text { Вартість згодованого комбіко- } \\
\text { рму на загальний приріст іхтіо- } \\
\text { маси, грн }\end{array}$ & 9570,08 & 8261,25 & 9074,42 & 10160,51 & 9715,40 \\
\hline $\begin{array}{l}\text { Вартість корму, затраченого на } \\
\text { 1 кг приросту іхтіомаси, грн }\end{array}$ & 68,78 & 73,62 & 70,37 & 65,68 & 67,17 \\
\hline $\begin{array}{l}\text { Собівартість 1 кг приросту іхті- } \\
\text { омаси, грн }\end{array}$ & 98,26 & 105,18 & 100,53 & 93,83 & 95,96 \\
\hline
\end{tabular}

Примітка. у иінах 2017 року

Можна констатувати, що збільшення вмісту у комбікормі лізину і метіоніну до рівня 3,1 і 1,05 \% призводить до збільшення приросту іхтіомаси за основний період досліду на 11,2-37,9 \%, тоді як подальше підвищення рівнів цих амінокислот дещо знижує економічні показники вирощування форелі. Встановлено, що у результаті неоднакових витрат корму на 1 кг приросту маси риб його вартість та витрати на загальний приріст іхтіомаси помітно різнилися по групах. Це, в свою чергу, вплинуло на собівартість 1 кг приросту іхтіомаси цьоголітків форелі, яка виявилася найнижчою у риб, які споживали корм із вмістом лізину і метіоніну на рівні 3,1 і 1,05 \% відповідно (4-а група). Зокрема, за згаданим показником вони переважали аналогів усіх інших груп, відповідно (за схемою досліду) на 4,7; 12,1; 7,1 i $2,3 \%$.

Отже, з економічної точки зору, виходячи з отриманих результатів, цьоголітків форелі до маси 10 г рекомендовано вирощувати на комбікормах з вмістом лізину і метіоніну на рівні 3,1 і 1,05 \% відповідно, тоді як підвищення цих амінокислот у кормі до рівня 3,2 і 1,1% відповідно є економічно не доцільним.

\section{Висновки:}

1. Використання у годівлі цьоголітків форелі з масою до 10 г комбікормів 3 підвищеною амінокислотною поживністю (3,1 \% лізину, 1,05 \% метіоніну) супроводжується збільшення їхньої маси на $9,2 \%(\mathrm{p}<0,05)$ та інтенсивності росту - на 4,1-9,3 \%, порівняно з аналогами, що споживали корм із вмістом лізину 3,0 \% та метіоніну 1,0 \%. Зменшення цих амінокислот до рівнів 2,8 і 0,9 \% відповідно сприяє вірогідному зменшенню ( $<0,01)$ маси на $14,1 \%$, та зниженню інтенсивності росту на 8,7-17,3\%. 
2. Доведено, що різний рівень амінокислотного живлення цьоголітків форелі достовірно $(\mathrm{p}<0,01)$ впливав на наростання маси піддослідних риб. Частка впливу даного фактору становила 61,4 \%, що на 22,8 \% більше, порівняно 3 впливом інших чинників.

3. Встановлено, що за вирощування цьоголітків райдужної форелі до маси 10 г згодовування їм комбікормів із вмістом лізину і метіоніну на рівні 3,1 i $1,05 \%$ сприяє зниженню витрат корму на одиницю приросту маси на 12,5 \%, порівняно з використанням кормів з рівнями цих амінокислот 2,8 і 0,9 \% відповідно. При цьому збереженість піддослідних риб перебувала в межах 76,0 -77,3 \%.

4. У результаті аналізу виробництва продукції форелівництва за показниками максимальної продуктивності та економічними критеріями оптимізації, для годівлі цьоголітків форелі рекомендується використовувати повнораціонні комбікорми з рівнем лізину $-3,1 \%$ та метіоніну $-1,05 \%$.

\section{Бібліографічний список}

1. Сгоров Б. В., Фігурська Л. В. Стан та перспективи розвитку форелівництва у рибоводних господарствах України. Зернові продукти і комбікорми. 2011. № 2. С. 37-39.

2. Шерман І. М., Гринжевський М. В., Желтов Ю. О. Наукове обгрунтування раціональної годівлі риб. Київ : Вища освіта, 2002. 128 с.

3. Щербина М. А., Гамыгин Е. А. Кормление рыб в пресноводной аквакультуре. Москва : ВНИРО, 2006. 360 с.

4. Cowey C. B. Nutrition : estimating requirements of rainbow trout. Aquaculture. 1992. № 100. P. 177-189.

5. Food and Agriculture Organization of the United Nations. El estado mundial de la pesca y la acuicultura. Contribución a la seguridad alimentaria y la nutrición para todos. Roma : Food and Agriculture Organization of the United Nations, 2016. 224 p.

6. Jobling M. Fish nutrition research : Past, present and future. Aquaculture International. 2016. № 24. P. 767-786.

7. Bureau D. P., Encarnação P. M. Adequately Defining the Amino Acid Requirements of Fish: The Case Example of Lysine. Materiales del VIII Simposium Internacional de Nutrición Acuícola. 15-17 Noviembre. Universidad Autónoma de Nuevo León, Monterrey, Nuevo León, México, 2006. P. 29-54.

8. Галоян Л. Л., Грициняк І. І., Драган Л. П. Вплив згодовування комбікорму «Aller Aqua» на вміст вільних амінокислот у м'язах і печінці струмкової (Salmo trutta linnaeus, 1758) та райдужної (Oncorhynchus mykiss walbaum, 1792) форелей. Рибогосподарська наука Украӥни. 2017. № 4. С. 112-119.

9. Bae J.-Y., Ok I.-H., Lee S. S., Hung S. O. Min T. S., Bai S. C. Reevaluation of dietary methionine requirement by plasma methionine and ammonia concentrations in surgically modified rainbow trout, Oncorhynchus mykiss. Asian-Australasian Journal of Animal Sciences. 2011. № 24 (7). P. 974-981.

10. Barnes M. E., Brown M. L., Rosentrater K. A. Juvenile rainbow trout responses to diets containing distillers dried grain with solubles, phytase, and amino acid supplements. Open Journal of Animal Sciences. 2012. № 2 (2). P. 69-77.

11. Остроумова И. Н. Биологические основы кормления рыб. СанктПетербург : ГОНИОРХ, 2001.372 с.

12. Желтов Ю. А. Протеин и аминокислоты в кормах для выращивания разного вида и возраста рыб. Луганск : АСТРА-Плюс, 2014. 156 с.

13. Инструкция по разведению радужной форели / сост. А. Н. Канидьев. Москва : ВНИИПРХ, 1985. 59 с. 
14. Вода рибогосподарських підприємств. Загальні вимоги та норми : СОУ - 05.01.-37-385:2006. Київ : Міністерство аграрної політики України. 2006. $15 \mathrm{c}$.

15. Плохинский Н. А. Руководство по биометрии для зоотехников. Москва : Колос, 1969. 246 с.

\section{References}

1. Yehorov, B. V., \& Fihurska, L. V. (2011). Stan ta perspektyvy rozvytku forelivnytstva u rybovodnykh hospodarstvakh Ukrainy [Status and prospects of trout farming development in fish farms of Ukraine]. Zernovi produkty i kombikormy - Grain products and compound feeds, 2, 37-39 [in Ukranian].

2. Sherman, I. M., Hrynzhevskyi, M. V., \& Zheltov, Yu. O. (2002). Naukove obhruntuvannia ratsionalnoi hodivli ryb [Scientific substantiation of rational feeding of fish]. Kyiv : Vyshcha osvita [in Ukranian].

3. Shcherbina, M. A., \& Gamygin, E. A. (2006). Kormlenie ryb v presnovodnoj akvakul'ture [Feeding fish in freshwater aquaculture] Moskva : VNIRO [in Ukranian].

4. Cowey, C. B. (1992). Nutrition: estimating requirements of rainbow trout. Aquaculture, 100, 177-189.

5. FAO (Food and Agriculture Organization of the United Nations) (2016). El estado mundial de la pesca y la acuicultura. Contribución a la seguridad alimentaria y la nutrición para todos. Roma: FAO (Food and Agriculture Organization of the United Nations).

6. Jobling, M. (2016). Fish nutrition research : Past, present and future. Aquaculture International, 24, 767-86.

7. Bureau, D. P., \& Encarnação, P. M. (2006) Adequately Defining the Amino Acid Requirements of Fish: The Case Example of Lysine. Materiales del VIII Simposium Internacional de Nutrición Acuícola (15-17 Novembre 2006). Universidad Autónoma de Nuevo León, Monterrey, Nuevo León, México, 29-54.

8. Haloian, L. L., Hrytsyniak, I. I., \& Drahan, L. P. (2017). Vplyv zghodovuvannia kombikormu «Aller Aqua» na vmist vilnykh aminokyslot u miazakh i pechintsi strumkovoi (Salmo trutta linnaeus, 1758) ta raiduzhnoi (Oncorhynchus mykiss walbaum, 1792) forelei [The effect of feeding "Aller Aqua" feed on the content of free amino acids in the muscles and liver of brown (Salmo trutta linnaeus, 1758) and rainbow (Oncorhynchus mykiss walbaum, 1792) trout]. Rybohospodarska nauka Ukrainy - Fisheries science of Ukraine, 4, 112-119 [in Ukranian].

9. Bae, J.-Y., Ok, I.-H., Lee S. S., Hung, S. O. Min, T. S., Bai, S. C. (2011). Reevaluation of dietary methionine requirement by plasma methionine and ammonia concentrations in surgically modified rainbow trout, Oncorhynchus mykiss. AsianAustralasian Journal of Animal Sciences, 24 (7), 974-981.

10. Barnes, M. E., Brown, M. L., \& Rosentrater, K. A. (2012). Juvenile rainbow trout responses to diets containing distillers dried grain with solubles, phytase, and amino acid supplements. Open Journal of Animal Sciences, 2 (2), 69-77.

11. Ostroumova, I. N. (2001). Biologicheskie osnovy kormleniya ryb [The biological basis of fish feeding]. Sankt-Peterburg : GONIORH [in Russian].

12. Zheltov, Yu. A. (2014). Protein i aminokislotyi v kormah dlya vyiraschivaniya raznogo vida i vozrasta ryib [Protein and amino acids in feed for rearing fish of different species and ages]. Lugansk : ASTRA-Plyus [in Russian].

13. Instrukciya po razvedeniyu raduzhnoj foreli [Instructions for breeding rainbow trout] (1985). Moscow : VNIIPRH [in Russian]. 
14. Voda rybohospodarskykh pidpryiemstv. Zahalni vymohy ta normy [Water of fishery enterprises. General requirements and norms]. SOU - 05.01.-37-385:2006. Kyiv : Ministerstvo ahrarnoi polityky Ukrainy [in Russian].

15. Plohinskij, N. A. (1969). Rukovodstvo po biometrii dlya zootekhnikov [Biometrics guide for zootechnicians]. Moskva : Kolos [in Russian].

\section{ВЛИЯНИЕ АМИНОКИСЛОТНОГО ПИТАНИЯ НА ПРОДУКТИВНОСТЬ СЕГОЛЕТОК РАДУЖНОЙ ФОРЕЛИ}

Кондратюк В. Н., Наџиональный университет биоресурсов и природопользования Украиньл.

В статье рассмотрены вопросы эффективности использования полнорационных комбикормов с разными уровнями лизина и метионина за выращивание сеголеток радужной форели до массы 10 г. Целью опыта предполагалось установить влияние различных уровней аминокислотного питания форели на показатели ее продуктивности. Для этого по методу аналогов было сформировано пять подопытных групп сеголеток. Опыт длился 45 суток и делился на два периода: уравнительный (5 суток) и основной (40 суток). В уравнительныий период подопытная рыба употребляла комбикорм контрольной группь. В основной период уровень лизина и метионина в экспериментальных комбикормах для различных подопытных групп форели колебался от 2,8 до 3,2 \% и от 0,90 до 1,10\% соответственно.

В результате проведенных исследований установлено, что использование в кормлении сеголеток форели массой до 10 г комбикормов с повышенной аминокислотной питательностью (3,1\% лизина, 1,05\% метионина) сопровождается увеличением их массы на 9,2\% (p<0,05) и интенсивности роста - на 4,1-9,3\% по сравнению с аналогами, потреблявших корм с содержанием лизина 3,0 \% и метионина 1,0\%. Уменьшение этих аминокислот к уровням 2,8 и 0,90\% соответственно способствует достоверному уменьшению $(p<0,01)$ массы рыб на 14,1\%, и снижению интенсивности роста на 8,7-17,3\%.

Доказано, что разный уровень аминокислотного питания форели достоверно $(p<0,01)$ влиял на массу подопытных рыб. Доля влияния данного фактора составляет 61,4\%, что на 22,8 \% больше по сравнению с влиянием других факторов.

В проиессе исследований было установлено, что за выращивание сеголеток радужной форели до массы 10 г скармливания им комбикормов с содержанием лизина и метионина на уровне 3,1 и 1,05 \% способствует снижению затрат корма на единицу прироста массы на 12,5\% по сравнению с использованием кормов с уровнями этих аминокислот 2,8 и 0,90\% соответственно. При этом сохранность подопытных рыб на протяжении всего опыта отвечала нормативнылм показателям в форелеводства и находилась в пределах 76,0-77,3\%.

Анализом полученных рыбоводческих результатов установлено, что при производстве продукции форелеводства по показателям максимальной производительности и экономическим критериям оптимизации рекомендуется для кормления сеголеток радужной форели использовать полнорационные комбикорма с уровнем лизина $3,1 \%$ и метионина $1,05 \%$.

Ключевые слова: радужная форель, кормление рыб, комбикорма, лизин, метионин, продуктивность, экономическая эффективность. 
THE INFLUENCE OF AMINO ACID NUTRITION ON THE PRODUCTIVITY OF RAINBOW TROUT

\section{Ukraine}

Kondratiuk V. M., National University of Life and Environmental Sciences of

The article considers the effectiveness of complete feed with different levels of lysine and methionine for growing rainbow trout up to $10 \mathrm{~g}$. The experiment aimed to establish the effect of different levels of amino acid nutrition of trout on its productivity. For this purpose, five experimental groups of this year were formed by the method of analogues. The experiment lasted 45 days and was divided into two periods: equalization (5 days) and main (40 days). During the equalization period, the experimental fish consumed feed of the control group. In the main period, the level of lysine and methionine in experimental feeds for different experimental groups of trout ranged from 2.8 to $3.2 \%$ and from 0.90 to $1.10 \%$, respectively.

As a result of research, it was found that the use of trout weighing up to $10 \mathrm{~g}$ of feed with high amino acid nutrition (3.1\% lysine, $1.05 \%$ methionine) in the feeding of this year is accompanied by an increase in their weight by $9.2 \%(p<0.05)$ and growth intensity - by 4.1-9.3\%, compared with analogues who consumed feed with the content of lysine of $3.0 \%$ and methionine of $1.0 \%$. The reduction of these amino acids to the levels of 2.8 and $0.9 \%$, respectively, contributes to a probable decrease $(p<0.01)$ in the weight of fish by $14.1 \%$, and a decrease in growth intensity by 8.7-17.3\%.

It was proved that different levels of amino acid nutrition of young trout significantly $(p<0.01)$ affected the weight of experimental fish. The share of influence of this factor is $61.4 \%$, which is $22.8 \%$ more than the influence of other factors.

In the course of research, it was determined that when growing rainbow trout this year up to $10 \mathrm{~g}$, feeding them compound feeds with lysine and methionine content of 3.1 and $1.05 \%$ helps to reduce feed costs per unit weight gain by $12.5 \%$, compared with using feeds with levels of these amino acids of 2.8 and $0.9 \%$, respectively. At the same time, the safety of the experimental fish throughout the experiment corresponded to the normative indicators in trout farming and was in the range of 76.0-77.3\%.

The analysis of the obtained fish farming results showed that for the production of trout products according to the indicators of maximum productivity and economic optimization criteria it is recommended to use complete feed with a level of $3.1 \%$ lysine and $1.05 \%$ methionine for feeding rainbow trout.

Keywords: rainbow trout, fish feeding, compound feeds, lysine, methionine, productivity, economic efficiency. 